\title{
BIOMECHANICAL PARAMETERS CHARACTERISING THE FOOT DURING NORMAL GAIT
}

\author{
Arina SEUL, Aura MIHAI* , Antonela CURTEZA, Mariana COSTEA, Bogdan SÂRGHIE \\ "Gheorghe Asachi" Technical University of lasi, Doctoral School, Faculty of Industrial Design and Business Management, 28 \\ Mangeron, 700050, lasi, Romania
}

\section{BIOMECHANICAL PARAMETERS CHARACTERISING THE FOOT DURING NORMAL GAIT}

ABSTRACT. The biomechanical analysis allows to understand the normal and pathological gait, the mechanics of neuromuscular control, and last but not least, allows the visualisation of the effects of footwear on human gait or feet. Biomechanical analyses are very important for the footwear development process, as they can identify the incorrect loading of the foot or the incorrect gait pattern, thus avoiding the occurrence of deformations. This paper aims to create an average representative model of barefoot loading based on an extended group of participants by applying an optimal procedure for measuring biomechanical parameters. The variation of four basic biomechanical parameters, namely force, pressure, contact time and contact area, was measured using a pressure platform and a specialised software system. The data was collected from 32 healthy females, without particularities regarding foot health and the practice of performance sports, aged between 18 and 30 years, divided into three size groups $-36,37$ and 38 . The T-Student test was applied to verify if there are significant differences between the left and right foot. Statistical indicators for each parameter were calculated, in order to characterize and establish the degree of variation of the obtained values, as follows: mean, standard deviation, minimum and maximum values, the amplitude of variation and coefficient of variation (CV). The study results confirm that the obtained mean values can be used as input data to load the foot and perform virtual simulations of footwear products.

KEYWORDS: foot, biomechanics, normal gait

PARAMETRII BIOMECANICI CARE CARACTERIZEAZĂ PICIORUL ÎN TIMPUL MERSULUI NORMAL

REZUMAT. Analiza biomecanică permite înțelegerea mersului normal și patologic, mecanica controlului neuromuscular și, nu în ultimul rând, permite vizualizarea efectelor încălțămintei asupra mersului uman și a picioarelor. Analizele biomecanice sunt foarte importante pentru procesul de dezvoltare a încălțămintei, deoarece permit identificarea încărcării incorecte a piciorului sau depistarea modelului incorect al mersului, evitând astfel apariția deformațiilor. Această lucrare are drept scop crearea unui model mediu reprezentativ de încărcare a piciorului desculț bazat pe un grup extins de participanți prin aplicarea unei proceduri optime pentru măsurarea parametrilor biomecanici. Variația a patru parametri biomecanici de bază, și anume forța, presiunea, timpul de contact și suprafața de contact, a fost măsurată utilizând o platformă de presiuni plantare și un sistem software specializat. Studiul s-a realizat pentru un eșantion de 32 de persoane de sex feminin, fără anumite particularități referitoare la starea de sănătate a picioarelor și practicarea sporturilor de performanță, cu vârsta cuprinsă între 18-30 de ani, împărțite pe 3 grupuri de mărimi, respectiv 36, 37 și 38 în sistem francez. Testul TStudent a fost aplicat pentru a verifica dacă există diferențe semnificative între valorile pentru piciorul stâng și cel drept. Au fost calculați indicatorii statistici pentru fiecare parametru analizat în vederea caracterizării și stabilirii gradului de variație a valorilor obținute, și anume: media aritmetică, abaterea standard, minimul, maximul, amplitudinea variației și coeficientul de variație. Rezultatele studiului confirmă faptul că valorile medii obținute pot fi utilizate ca date de intrare pentru a încărca piciorul și a simula comportamentul încălțămintei. CUVINTE CHEIE: picior, biomecanica mersului, mers normal

\section{LES PARAMÈTRES BIOMÉCANIQUES QUI CARACTÉRISENT LE PIED PENDANT LA DÉMARCHE NORMALE}

RÉSUMÉ. L'analyse biomécanique permet de comprendre la démarche normale et pathologique, la mécanique du contrôle neuromusculaire et, enfin et surtout, permet de visualiser les effets des chaussures sur la démarche et les pieds humains. Les analyses biomécaniques sont très importantes pour le processus de développement de la chaussure, car elles permettent l'identification de la charge incorrecte du pied ou la détection du modèle de démarche incorrect, évitant ainsi l'apparition de déformations. Cet article vise à créer un modèle moyen représentatif de la charge des pieds nus basé sur un groupe étendu de participants en appliquant une procédure optimale pour mesurer les paramètres biomécaniques. La variation de quatre paramètres biomécaniques de base, à savoir la force, la pression, le temps de contact et la surface de contact, a été mesurée à l'aide d'une plate-forme de pression plantaire et d'un système logiciel spécialisé. L'étude a été menée pour un échantillon de 32 femmes, sans aucune particularité concernant la santé des pieds et les sports de performance, âgées de 18 à 30 ans, réparties en 3 groupes de taille, respectivement 36, 37 et 38 dans le système français. Le test T-Student a été appliqué pour voir s'il y avait des différences significatives entre les valeurs pour le pied gauche et le pied droit. Des indicateurs statistiques ont été calculés pour chaque paramètre analysé afin de caractériser et d'établir le degré de variation des valeurs obtenues, à savoir : la moyenne arithmétique, l'écart type, le minimum, le maximum, l'amplitude de variation et le coefficient de variation. Les résultats de l'étude confirment que les valeurs moyennes obtenues peuvent être utilisées comme données d'entrée pour charger le pied et simuler le comportement de la chaussure.

MOTS CLÉS: pied, biomécanique de la démarche, démarche normale

\footnotetext{
* Correspondence to: Aura MIHAI, „Gheorghe Asachi” Technical University of Iasi, Faculty of Industrial Design and Business Management,
} Blvd., 29 Dimitrie Mangeron, 700050, Iasi, Romania, aura.mihai@academic.tuiasi.ro 


\section{INTRODUCTION}

The foot has a complex anatomical and biomechanical structure, which ensures the transmission of the forces created during its interaction with the ground [1] and fulfils multiple functions such as support, balance, thermoregulation [2, 3] force absorption, impact attenuation and body displacement [4]. These aspects are considered and evaluated by biomechanics - the study of human movement.

The biomechanical analysis allows understanding the normal and pathological gait [5], the mechanics of neuromuscular control [6], and visualising the effects of footwear on human gait or feet. Biomechanical analyses are very important for the footwear development process, as they can identify the improper loading of the foot or the incorrect gait pattern, thus avoiding the occurrence of deformations [7].

Specific studies include two components: kinematic and kinetic analyses. The kinematic analysis evaluates movement patterns, including body movement and specific angles [8], ignoring the generated forces [9]. Kinematic components of the foot evaluated during movement are width, foot deformation under the influence of the load while walking, medial longitudinal arch length, the angle between the ankle and the foot at the initial contact, ankle movement, etc. [10].

The term kinetics is used in biomechanics to describe the relationship between forces and movement produced in the joints. These movements are produced by both internal forces (derived mainly from muscle activity and bone contact) and external forces (derived mainly from body weight or reaction forces). Kinetic studies correlate joint's angles and movements in dynamics with joint moments [11]. The main kinetic parameters are force, pressure and centre of pressure.

Human movement is composed of different rotational and translational movements, which are the result of the action of a complex field of forces - normal (perpendicular) and tangential (parallel) or torques acting on the body $[1,9,12]$.
The field consists of two categories of forces: external and internal. The tensions in the muscle groups represent the active internal forces. During walking, muscle forces are added to inertia forces, which occurs due to the interaction of different body elements [2]. The most common external force applied to the human body while walking is the reaction force. This force is a threedimensional vector comprising a vertical component and two horizontal components. In the mid-stance phase, the foot exerts an exchange of forces with the ground. In the heel strike phase, the human foot touches the support, generating two forces in the $x$ direction and the $y$-direction. The foot passes through the mid-stance phase immediately after the entire plantar surface touches the support. In the next stage, the foot exerts the most significant force to ensure that the body moves forward. The support reacts with the same amount of force in the opposite direction [13]. The magnitude of the ground reaction forces depends on the speed and body weight [14].

The extent and direction of the internal forces are significant. According to Jacob [15], the force applied on the first metatarsal reaches about $119 \%$ of body weight, while the second metatarsal is subjected to a high bending moment, with a resulting force of about $45 \%$ of the body weight acting on foot.

In the first $100 \mathrm{~ms}$ of each step, the force acting in the $\mathrm{Z}$ direction reaches $\mathrm{a}$ maximum of $120 \%$ of body weight, decreasing to about $60-80 \%$ of body weight during support on one foot. The centre of gravity is located in the middle of the pelvis and makes a sinusoidal movement while walking. The horizontal reaction forces are considerably smaller than the vertical reaction force. The horizontal reaction force acting in the $Y$ direction has an amplitude of $25 \%$ of the body weight [14].

Wiedemeijer and Otten [16] and Stefanyshyn et al. [17] have analysed the distribution of forces while walking in highheeled shoes. This condition significantly influences angles and force distributions. The maximum vertical reaction force is about $5 \%$ higher than walking with a low heel in the impact phase. The reaction force, in this case, 
is higher in the forward and rearward directions and corresponds to an increase in deceleration and acceleration forces in the vertical direction.

During walking barefoot or with low heel shoes, the heel takes on a load of about $57 \%$ of body weight and the metatarsals $43 \%$. During walking with a $10 \mathrm{~cm}$ heel, about $100 \%$ of the weight is applied to the metatarsals. The most balanced weight distribution is made on a $2 \mathrm{~cm}$ heel (approximately 50\% on each vector). The calcaneus is loaded on 25$43 \%$ of body weight. The metatarsals carry $57-$ $75 \%$ of body weight for medium-high heels [7].

The distribution of force also changes during running. A lower load and a more evenly distributed force were identified in the heel strike phase [18].

Body weight, speed, step length, type and structure of footwear are the factors that influence the distribution of plantar pressure [19].

Biomechanical measurements of the pressure distribution between the plantar surface of the foot and the support plane provide valuable information on the structure and function of the foot [14], which can indicate the impact of footwear or the necessary shape of the insole [7] and provide suggestions for improving design structure of footwear $[19,20]$.

During human walking, the centre of pressure advances during each step, creating a rolling motion between the foot and the support [21]. The average pressure distribution determines the centre of pressure. It could be standardised according to the length of the foot [22].

During the mid-stance phase, the maximum plantar pressure is transferred from the heel area to the rear-foot area [3].

The contact pressure at the metatarsophalangeal joints intensifies and reaches its maximum value in the push-off phase. The maximum contact pressure in the metatarsal area during push-off increases at least four times (third metatarsophalangeal joint) and up to 11 times (first metatarsophalangeal joint) compared to the heel strike phase [23].
Both peak plantar pressure and ground reaction forces can vary at similar walking speeds, as they can be produced by different combinations of length and cadence [14]. In general, maximum pressures and total force increase with walking speed.

The type of footwear influences the pressure distribution. Comfortable footwear contributes significantly to a balanced distribution of pressure on the plantar surface of the foot. Shoes with flexible soles reduce the plantar pressure and contribute to the proper functioning of the foot [19].

Several studies have investigated the influence of the heel on pressure distribution. During high-heeled walking, the joints showed different loading patterns [23]. This condition influenced the increase in pressure in the peak area compared to the barefoot. The maximum pressure is observed in the rear-foot area (hallux), followed by the midfoot and forefoot. Walking in high-heeled shoes resulted in a $30 \%$ increase in peak pressures in the II-IV metatarsal area compared to walking in lowheeled shoes [16, 24].

The 3D biomechanical analysis that includes a description of the movement of different anatomical segments of the foot is the most common assessment of the foot and gait. A motion capture system and a force plate must perform both kinematic and kinetic (dynamic) analysis.

Plate $[13,3]$ and insole systems with inshoe sensors [14, 15] are used to register plantar pressures, both of which allow the determination of maximum pressures, weight distribution, surface and contact time, the position of the centre of pressure in both static and dynamic conditions [22, 25].

External forces, i.e., ground reaction forces, are measured using a force plate [3]. Intramuscular forces and Achilles' tendon forces are taken from electromyography and sensitive analysis of the centre of pressure $[26,27]$.

Kinematic parameters, such as the contact time, can be measured using highspeed cameras (i.e., MotionBLITZ EoSens ${ }^{\circledR}$ mini) [28].

There are complex systems with sensors (i.e., Vicon) [27, 29], which allow the simultaneous capture and determination of 
kinetic and kinematic parameters, such as: walking or running speed, duration of heel strike, mid-stance and push-off, cadence, impact index, maximum reaction force, average load rate, initial speed, initial tibia angle, initial ankle flexion angle.

This paper investigates the biomechanical parameters to create an average representative model of foot loading for an extended target group.

\section{EXPERIMENTAL}

\section{Materials and Methods}

\section{Equipment}

The biomechanical parameters were registered using the Footscan system produced by RS Scan International. The equipment consists of a pressure platform and a software system (Figure 1), ensuring the collection, visualisation, and processing of static and dynamic biomechanical measurements. This system is mentioned in several research studies [28, 30], and is also used by various institutions and specialised laboratories. The platform incorporates $5 \mathrm{~mm}$ $x 7 \mathrm{~mm}$ sensors that ensure the variation analysis of the pressures and forces for all the regions of the plantar footprint.

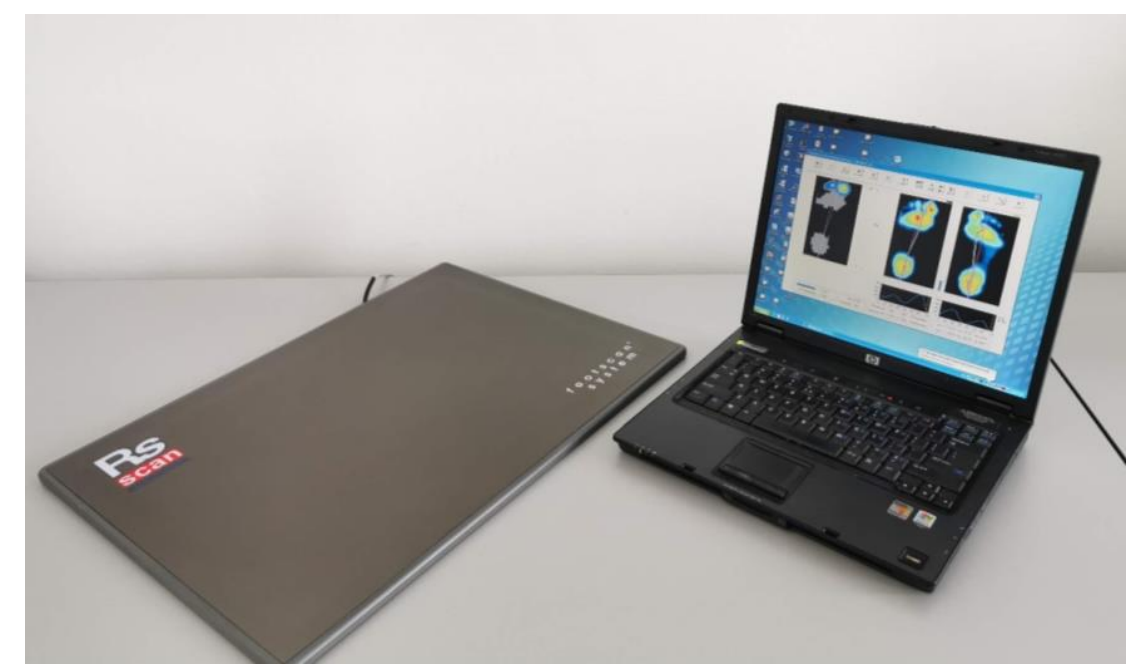

Figure 1. Footscan system

Subjects

The biomechanical study was made based on data collected from 32 volunteer subjects, female, representing students from the "Gheorghe Asachi" Technical University of lasi, 18-30 years old, wearing footwear size numbers 36 (group 1), 37 (group 2), 38 (group 3 ) in the French system. None of the subjects practice performance sports or other activities that could significantly influence the gait pattern. The subjects are included in the height range of $153-175 \mathrm{~cm}$ and weight range of $40-72 \mathrm{~kg}$.

\section{Method. Recording and Analysis of Biomechanical Parameters in Dynamics}

To obtain the most accurate results, a working methodology was developed. Each subject was asked to reproduce three types of barefoot gait: normal gait (N), slow gait (L) and fast gait $(R)$. The subjects established by themselves the specific speed for all three types of gait, considering the following ranges for total step time: normal gait $700-900 \mathrm{~ms}$, slow gait $900-1100 \mathrm{~ms}$, fast gait $500-700 \mathrm{~ms}$. The subjects were tested using the three-step approach considered the most suitable in terms of results [31, 32]. According to this protocol, the subjects contact the platform on 
the third step after initiating gait and walk a few more steps after platform contact. The invalid trials in which the contact between the foot and platform were not made correctly were not saved. The subjects repeated the same procedure with the opposite foot, thus recording values specific to the right and left foot. For each condition, three trials were

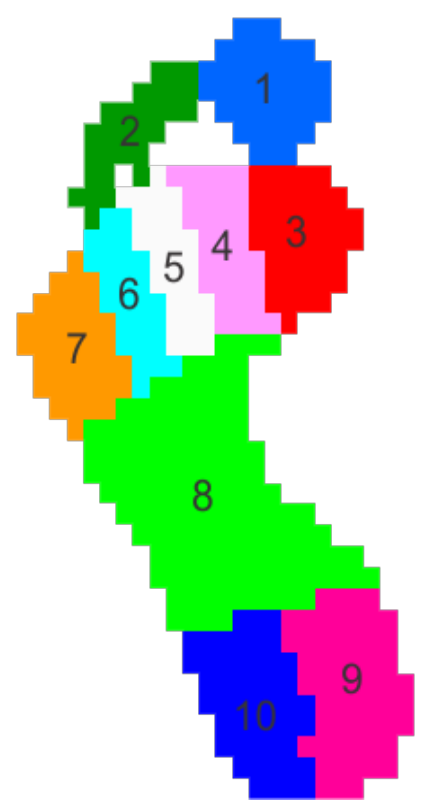

recorded, resulting

in 9 measurements/subject.

The plantar footprint is divided into 10 distinct regions (Figure 2) 242 [35]: 1 -toe I (Z1); 2 - toe II-V (Z2); 3 - metatarsal I (Z3); 4 metatarsal II (Z4); 5 -metatarsal III (Z5); 6 metatarsal IV (Z6); 7 - metatarsal V (Z7); 8 midfoot (Z8); 9 - heel medial (Z9); 10 - heel lateral (Z10).

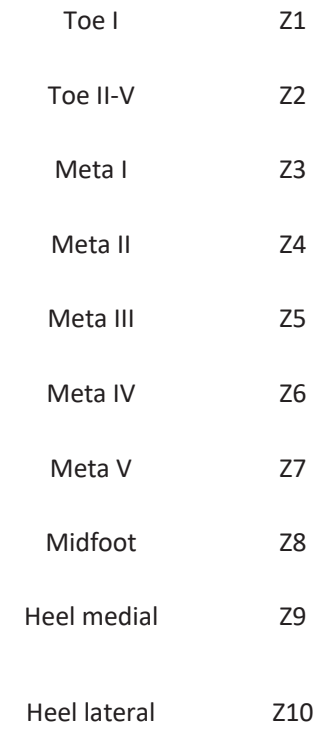

Figure 2. Anatomical division of the plantar footprint in 10 regions

The force $(N)$, contact area $\left(\mathrm{cm}^{2}\right)$, contact time $(\mathrm{ms})$, and pressure $\left(\mathrm{N} / \mathrm{cm}^{2}\right)$ for the 10 regions of the plantar surface were recorded and analysed using the Footscan system. Deviant values were excluded from the list, so the average of the tests was done with the remaining values.

The results were divided into three groups, according to the subjects' foot size, and the average values for the three trials for each analysed parameter were centralised in a table.

This paper presents the analysis of the biomechanical parameters during the normal gait.

\section{RESULTS AND DISCUSSIONS}

Verification of the Statistical Significance of the Differences between the Biomechanical Parameters of the Left and Right Foot Using the Student's Test and the Fisher's Test

The T-Student test was applied to confirm that there are no significant differences between the left and right foot. The averages of the set of values for the left and right foot for each of the 10 regions of the plantar footprint were compared, taking into account the following biomechanical parameters: force $(\mathrm{N})$, contact area $\left(\mathrm{cm}^{2}\right)$, contact time (ms) and pressure $\left(\mathrm{N} / \mathrm{cm}^{2}\right)$.

The calculated values are compared with $p=0.05$ for a probability of $95 \%$ to determine if the results obtained are statistically significant. The values must be 
greater than $p=0.05$ to confirm the null hypothesis.

The Fisher test was used with $p=0.05$ to verify that the variances in terms of biomechanical parameter values for the left foot did not differ significantly from the variances for the right foot.

According to both tests (Table 1), the null hypothesis for the contact area parameter was not confirmed, which highlights that most subjects have differences between the gait patterns of the left (L) foot compared to the right $(R)$ foot in terms of the area of the plantar surface that contacts the ground. While in the case of force, pressure, and contact time parameters, the opposite is demonstrated - namely, there are no significant differences between the left and right foot. As a result, using the averages between the two feet in the next stage is possible. These hypotheses validate that the values are representative of the population.

Table 1: T and $\mathrm{F}$ Test results

\begin{tabular}{|c|c|c|c|c|c|c|c|c|c|c|c|}
\hline Size 36 & & $\mathrm{Z1}$ & $\mathrm{Z2}$ & Z3 & Z4 & Z5 & Z6 & $\mathrm{Z7}$ & Z8 & Z9 & $\mathrm{Z10}$ \\
\hline \multirow{2}{*}{ Force } & Test T & 0.279 & 0.382 & 0.321 & 0.480 & 0.890 & 0.759 & 0.485 & 0.013 & 0.314 & 0.532 \\
\hline & Test F & 0.691 & 0.501 & 0.795 & 0.269 & 0.429 & 0.858 & 0.532 & 0.264 & 0.102 & 0.184 \\
\hline \multirow{2}{*}{ Contact area } & Test T & 0.135 & 0.044 & 0.002 & 0.000 & 0.000 & 0.001 & 0.002 & 0.814 & 0.000 & 0.000 \\
\hline & Test F & 0.012 & 0.060 & 0.429 & 0.354 & 0.559 & 0.579 & 0.985 & 0.981 & 0.803 & 0.922 \\
\hline \multirow{2}{*}{ Contact time } & Test T & 0.316 & 0.971 & 0.743 & 0.446 & 0.944 & 0.999 & 0.839 & 0.350 & 0.294 & 0.519 \\
\hline & Test F & 0.392 & 0.967 & 0.315 & 0.425 & 0.625 & 0.710 & 0.323 & 0.340 & 0.732 & 0.958 \\
\hline \multirow{2}{*}{ Pressure } & Test T & 0.499 & 0.712 & 0.039 & 0.669 & 0.215 & 0.526 & 0.896 & 0.005 & 0.048 & 0.434 \\
\hline & Test F & 0.619 & 0.512 & 0.039 & 0.903 & 0.997 & 0.744 & 0.850 & 0.147 & 0.028 & 0.155 \\
\hline \multicolumn{2}{|l|}{ Size 37} & $\mathrm{Z1}$ & $\mathrm{Z2}$ & Z3 & Z4 & Z5 & Z6 & $\mathrm{Z7}$ & Z8 & Z9 & $\mathrm{Z10}$ \\
\hline \multirow{2}{*}{ Force } & Test T & 0.263 & 0.202 & 0.212 & 0.392 & 0.938 & 0.220 & 0.413 & 0.005 & 0.707 & 0.548 \\
\hline & Test F & 0.448 & 0.094 & 0.003 & 0.925 & 0.247 & 0.080 & 0.856 & 0.175 & 0.058 & 0.045 \\
\hline \multirow{2}{*}{ Contact area } & Test T & 0.105 & 0.605 & 0.002 & 0.000 & 0.000 & 0.007 & 0.001 & 0.339 & 0.000 & 0.000 \\
\hline & Test F & 0.982 & 0.942 & 0.282 & 0.968 & 0.080 & 0.137 & 0.040 & 0.837 & 0.981 & 0.413 \\
\hline \multirow{2}{*}{ Contact time } & Test T & 0.420 & 0.473 & 0.809 & 0.681 & 0.794 & 0.744 & 0.075 & 0.247 & 0.836 & 0.650 \\
\hline & Test F & 0.343 & 0.603 & 0.194 & 0.945 & 0.672 & 0.632 & 0.000 & 0.532 & 0.581 & 0.594 \\
\hline \multirow{2}{*}{ Pressure } & Test T & 0.648 & 0.147 & 0.601 & 0.922 & 0.145 & 0.073 & 0.697 & 0.006 & 0.489 & 0.724 \\
\hline & Test F & 0.741 & 0.061 & 0.012 & 0.984 & 0.408 & 0.173 & 0.693 & 0.072 & 0.112 & 0.086 \\
\hline \multicolumn{2}{|l|}{ Size 38} & $\mathrm{Z1}$ & $\mathrm{Z2}$ & Z3 & Z4 & $\mathrm{Z5}$ & Z6 & $\mathrm{Z7}$ & Z8 & Z9 & $\mathrm{Z10}$ \\
\hline \multirow{2}{*}{ Force } & Test T & 0.096 & 0.795 & 0.596 & 0.287 & 0.555 & 0.533 & 0.517 & 0.364 & 0.638 & 0.896 \\
\hline & Test F & 0.317 & 0.896 & 0.224 & 0.577 & 0.636 & 0.812 & 0.436 & 0.229 & 0.539 & 0.527 \\
\hline \multirow{2}{*}{ Contact area } & Test T & 0.003 & 0.789 & 0.009 & 0.006 & 0.001 & 0.013 & 0.228 & 0.432 & 0.050 & 0.002 \\
\hline & Test F & 0.378 & 0.321 & 0.099 & 0.833 & 0.842 & 0.129 & 0.852 & 0.544 & 0.123 & 0.445 \\
\hline \multirow{2}{*}{ Contact time } & Test T & 0.587 & 0.881 & 0.726 & 0.667 & 0.630 & 0.297 & 0.583 & 0.525 & 0.668 & 0.396 \\
\hline & Test $\mathrm{F}$ & 0.761 & 0.411 & 0.632 & 0.343 & 0.174 & 0.139 & 0.904 & 0.236 & 0.212 & 0.307 \\
\hline \multirow{2}{*}{ Pressure } & Test T & 0.276 & 0.724 & 0.761 & 0.994 & 0.468 & 0.347 & 0.634 & 0.295 & 0.346 & 0.633 \\
\hline & Test F & 0.822 & 0.712 & 0.567 & 0.954 & 0.136 & 0.510 & 0.766 & 0.596 & 0.839 & 0.853 \\
\hline
\end{tabular}

Statistical Indicators for Characterisation and Variation of Biomechanical Parameters

The statistical indicators [33] which characterise the set of values are mean, standard deviation (S), the minimum, maximum, amplitude of variation (A), and the coefficient of variation (CV). The values of statistical indicators of measured biomechanical parameters are presented in Tables 2-5. 
Table 2: Statistical indicators for characterising the force distribution during normal gait

\begin{tabular}{|c|c|c|c|c|c|c|c|c|c|c|c|}
\hline Size 36 & $\begin{array}{c}\text { Number of } \\
\text { subjects }\end{array}$ & Z1 & $\mathrm{Z2}$ & Z3 & Z4 & $\mathrm{Z5}$ & Z6 & $\mathrm{Z7}$ & Z8 & Z9 & Z10 \\
\hline \multirow{7}{*}{ Force (N) } & Mean value & 159.4 & 9.2 & 54.7 & 125.2 & 156.5 & 113.3 & 42.0 & 38.3 & 244.3 & 186.7 \\
\hline & Min & 63.2 & 0.0 & 16.6 & 18.9 & 80.7 & 38.6 & 1.0 & 5.1 & 160.9 & 133.2 \\
\hline & Max & 241.3 & 26.1 & 96.7 & 202.9 & 229.0 & 220.7 & 84.0 & 69.6 & 326.9 & 272.9 \\
\hline & & & & & & & & & & & \\
\hline & $A$ & 178.1 & 26.1 & 80.1 & 184.0 & 148.3 & 182.1 & 83.0 & 64.5 & 166.0 & 139.7 \\
\hline & $\mathrm{S}$ & 60.4 & 7.6 & 28.9 & 50.3 & 41.2 & 52.9 & 31.4 & 23.3 & 63.8 & 46.0 \\
\hline & CV \% & 37.9 & 83.0 & 52.8 & 40.2 & 26.3 & 46.7 & 74.8 & 60.9 & 26.1 & 24.6 \\
\hline \multirow[t]{3}{*}{ Size 37} & $\begin{array}{c}\text { Number of } \\
\text { subjects }\end{array}$ & Z1 & $\mathrm{Z2}$ & Z3 & Z4 & Z5 & Z6 & $\mathrm{Z7}$ & Z8 & Z9 & Z10 \\
\hline & Mean value & 141.9 & 19.0 & 40.8 & 142.9 & 163.2 & 92.2 & 34.0 & 34.0 & 184.4 & 170.8 \\
\hline & Min & 57.8 & 0.0 & 0.4 & 50.8 & 76.6 & 40.3 & 5.1 & 4.1 & 106.0 & 75.0 \\
\hline \multirow{5}{*}{ Force $(\mathrm{N})$} & Max & 247.1 & 42.2 & 144.2 & 340.6 & 253.0 & 170.5 & 142.7 & 55.6 & 262.7 & 278.4 \\
\hline & & & & & & & & & & & \\
\hline & $A$ & 189.3 & 42.2 & 143.8 & 289.9 & 176.4 & 130.2 & 137.6 & 51.5 & 156.8 & 203.3 \\
\hline & $S$ & 62.9 & 14.3 & 36.7 & 83.8 & 52.6 & 33.8 & 36.5 & 15.2 & 49.0 & 61.7 \\
\hline & CV \% & 44.3 & 75.3 & 89.9 & 58.7 & 32.2 & 36.6 & 107.5 & 44.8 & 26.6 & 36.1 \\
\hline \multirow[t]{4}{*}{ Size 38} & $\begin{array}{c}\text { Number of } \\
\text { subjects }\end{array}$ & Z1 & $\mathrm{Z2}$ & Z3 & Z4 & $\mathrm{Z5}$ & Z6 & $\mathrm{Z7}$ & Z8 & Z9 & Z10 \\
\hline & Mean value & 201.2 & 48.2 & 79.9 & 166.7 & 180.2 & 115.5 & 40.1 & 44.9 & 256.7 & 215.6 \\
\hline & Min & 9.9 & 6.2 & 11.2 & 83.7 & 115.9 & 51.1 & 0.0 & 5.8 & 107.0 & 94.8 \\
\hline & Max & 345.7 & 177.5 & 188.8 & 270.4 & 282.7 & 273.9 & 111.7 & 133.5 & 471.5 & 381.8 \\
\hline \multicolumn{12}{|l|}{ Force (N) } \\
\hline & $A$ & 335.9 & 171.3 & 177.6 & 186.7 & 166.9 & 222.8 & 111.7 & 127.7 & 364.5 & 287.0 \\
\hline & $\mathrm{S}$ & 109.1 & 54.5 & 66.3 & 61.4 & 56.3 & 71.3 & 38.6 & 37.0 & 137.7 & 102.0 \\
\hline & CV \% & 54.2 & 113.2 & 83.0 & 36.9 & 31.2 & 61.7 & 96.3 & 82.3 & 53.7 & 47.3 \\
\hline
\end{tabular}

Table 3: Statistical indicators for characterising the contact time during normal gait

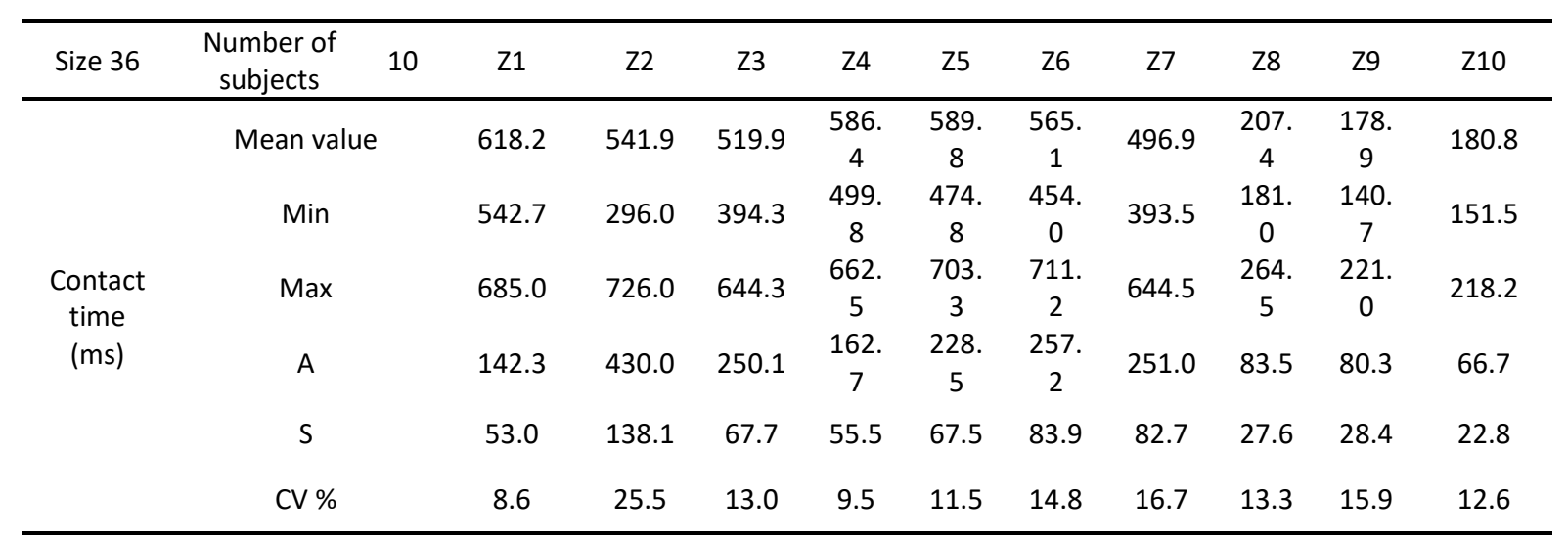


A. SEUL, A. MIHAI, A. CURTEZA, M. COSTEA, B. SÂRGHIE

\begin{tabular}{|c|c|c|c|c|c|c|c|c|c|c|c|c|}
\hline Size 37 & $\begin{array}{c}\text { Number of } \\
\text { subjects }\end{array}$ & 13 & $\mathrm{Z1}$ & $\mathrm{Z} 2$ & Z3 & Z4 & $\mathrm{Z} 5$ & Z6 & $\mathrm{Z7}$ & Z8 & Z9 & Z10 \\
\hline \multirow{6}{*}{$\begin{array}{l}\text { Contact } \\
\text { time } \\
\text { (ms) }\end{array}$} & \multicolumn{2}{|c|}{ Mean value } & 612.4 & 504.9 & 501.1 & $\begin{array}{c}585 . \\
8\end{array}$ & $\begin{array}{c}587 . \\
2\end{array}$ & $\begin{array}{c}575 . \\
5\end{array}$ & 488.4 & $\begin{array}{c}199 . \\
0\end{array}$ & $\begin{array}{c}173 . \\
1\end{array}$ & 178.5 \\
\hline & \multicolumn{2}{|l|}{ Min } & 563.5 & 0.0 & 93.0 & $\begin{array}{c}531 . \\
5\end{array}$ & $\begin{array}{c}521 . \\
8\end{array}$ & $\begin{array}{c}508 . \\
0\end{array}$ & 238.5 & $\begin{array}{c}107 . \\
7\end{array}$ & 86.5 & 120.0 \\
\hline & \multicolumn{2}{|l|}{ Max } & 675.0 & 672.5 & 650.0 & $\begin{array}{c}650 . \\
0\end{array}$ & $\begin{array}{c}658 . \\
5\end{array}$ & $\begin{array}{c}664 . \\
5\end{array}$ & 614.5 & $\begin{array}{c}338 . \\
8\end{array}$ & $\begin{array}{c}215 . \\
5\end{array}$ & 235.5 \\
\hline & \multicolumn{2}{|l|}{$A$} & 111.5 & 672.5 & 557.0 & $\begin{array}{c}118 . \\
5\end{array}$ & $\begin{array}{c}136 . \\
7\end{array}$ & $\begin{array}{c}156 . \\
5\end{array}$ & 376.0 & $\begin{array}{c}231 . \\
1\end{array}$ & $\begin{array}{c}129 . \\
0\end{array}$ & 115.5 \\
\hline & \multicolumn{2}{|l|}{$\mathrm{S}$} & 38.2 & 207.9 & 137.2 & 40.2 & 42.3 & 44.7 & 107.5 & 53.1 & 37.2 & 32.2 \\
\hline & \multicolumn{2}{|l|}{ CV \% } & 6.2 & 41.2 & 27.4 & 6.9 & 7.2 & 7.8 & 22.0 & 26.7 & 21.5 & 18.0 \\
\hline Size 38 & $\begin{array}{c}\text { Number of } \\
\text { subjects }\end{array}$ & 9 & $\mathrm{Z1}$ & $\mathrm{Z2}$ & Z3 & Z4 & $\mathrm{Z} 5$ & Z6 & $\mathrm{Z7}$ & Z8 & Z9 & Z10 \\
\hline \multirow{6}{*}{$\begin{array}{l}\text { Contact } \\
\text { time } \\
\text { (ms) }\end{array}$} & \multicolumn{2}{|c|}{ Mean value } & 633.0 & 625.6 & 575.4 & $\begin{array}{c}616 . \\
2\end{array}$ & $\begin{array}{c}611 . \\
9\end{array}$ & $\begin{array}{c}605 . \\
5\end{array}$ & 463.7 & $\begin{array}{c}228 . \\
6\end{array}$ & $\begin{array}{c}184 . \\
7\end{array}$ & 183.6 \\
\hline & \multicolumn{2}{|l|}{ Min } & 561.0 & 542.3 & 479.0 & $\begin{array}{c}535 . \\
0\end{array}$ & $\begin{array}{c}537 . \\
5\end{array}$ & $\begin{array}{c}520 . \\
5\end{array}$ & 0.0 & $\begin{array}{c}190 . \\
3\end{array}$ & $\begin{array}{c}148 . \\
2\end{array}$ & 158.0 \\
\hline & \multicolumn{2}{|l|}{ Max } & 795.0 & 721.3 & 766.0 & $\begin{array}{c}781 . \\
5\end{array}$ & $\begin{array}{c}700 . \\
0\end{array}$ & $\begin{array}{c}738 . \\
0\end{array}$ & 599.0 & $\begin{array}{c}315 . \\
5\end{array}$ & $\begin{array}{c}266 . \\
5\end{array}$ & 244.3 \\
\hline & \multicolumn{2}{|l|}{$A$} & 234.0 & 178.9 & 287.0 & $\begin{array}{c}246 . \\
5\end{array}$ & $\begin{array}{c}162 . \\
5\end{array}$ & $\begin{array}{c}217 . \\
5\end{array}$ & 599.0 & $\begin{array}{c}125 . \\
2\end{array}$ & $\begin{array}{c}118 . \\
3\end{array}$ & 86.3 \\
\hline & \multicolumn{2}{|l|}{$\mathrm{S}$} & 79.2 & 65.7 & 95.2 & 77.7 & 51.4 & 74.8 & 180.5 & 40.7 & 37.0 & 27.3 \\
\hline & \multicolumn{2}{|l|}{ CV \% } & 12.5 & 10.5 & 16.6 & 12.6 & 8.4 & 12.4 & 38.9 & 17.8 & 20.0 & 14.9 \\
\hline
\end{tabular}







Table 5: Statistical indicators for characterising the pressure distribution during normal gait

\begin{tabular}{|c|c|c|c|c|c|c|c|c|c|c|c|c|}
\hline Size 36 & Number of subjects & 10 & $\mathrm{Z1}$ & $\mathrm{Z2}$ & $\mathrm{Z3}$ & $\mathrm{Z4}$ & $\mathrm{Z5}$ & Z6 & $\mathrm{Z7}$ & Z8 & Z9 & $\mathrm{Z} 10$ \\
\hline \multirow{6}{*}{ Pressure $\left(\mathrm{N} / \mathrm{cm}^{2}\right)$} & Mean value & & 11.6 & 0.9 & 6.4 & 14.4 & 20.7 & 14.2 & 4.2 & 1.8 & 18.6 & 15.9 \\
\hline & Min & & 5.7 & 0.0 & 1.6 & 2.5 & 9.6 & 5.0 & 0.1 & 0.5 & 12.7 & 12.1 \\
\hline & Max & & 18.0 & 2.1 & 10.5 & 23.5 & 30.3 & 28.3 & 9.8 & 3.0 & 26.9 & 20.6 \\
\hline & A & & 12.3 & 2.1 & 8.9 & 21.0 & 20.7 & 23.3 & 9.7 & 2.5 & 14.3 & 8.5 \\
\hline & $S$ & & 3.9 & 0.7 & 3.2 & 5.9 & 5.7 & 6.8 & 3.2 & 0.9 & 4.8 & 3.0 \\
\hline & CV \% & & 33.5 & 84.3 & 49.6 & 41.2 & 27.6 & 47.7 & 75.6 & 49.8 & 26.0 & 19.0 \\
\hline Size 37 & Number of subjects & 13 & $\mathrm{Z1}$ & $\mathrm{Z2}$ & $\mathrm{Z3}$ & $\mathrm{Z4}$ & $\mathrm{Z5}$ & Z6 & $\mathrm{Z7}$ & Z8 & Z9 & $\mathrm{Z10}$ \\
\hline \multirow{6}{*}{ Pressure $\left(\mathrm{N} / \mathrm{cm}^{2}\right)$} & Mean value & & 10.8 & 1.4 & 4.2 & 15.3 & 21.0 & 11.1 & 3.6 & 1.4 & 13.1 & 13.8 \\
\hline & Min & & 4.5 & 0.0 & 0.1 & 6.3 & 10.4 & 4.9 & 0.5 & 0.4 & 7.8 & 5.9 \\
\hline & Max & & 19.8 & 3.4 & 12.4 & 31.3 & 31.3 & 20.2 & 17.0 & 2.5 & 19.3 & 21.0 \\
\hline & A & & 15.4 & 3.4 & 12.3 & 25.0 & 20.9 & 15.3 & 16.5 & 2.1 & 11.5 & 15.1 \\
\hline & $S$ & & 5.0 & 1.0 & 3.1 & 8.1 & 6.3 & 3.9 & 4.3 & 0.6 & 3.6 & 4.8 \\
\hline & CV \% & & 46.7 & 72.7 & 74.1 & 53.1 & 29.9 & 35.2 & 119.9 & 44.5 & 27.9 & 34.9 \\
\hline Size 38 & Number of subjects & 9 & $\mathrm{Z1}$ & $\mathrm{Z2}$ & $\mathrm{Z3}$ & Z4 & $\mathrm{Z5}$ & $\mathrm{Z6}$ & 27 & Z8 & Z9 & $\mathrm{Z10}$ \\
\hline \multirow{6}{*}{ Pressure $\left(\mathrm{N} / \mathrm{cm}^{2}\right)$} & Mean value & & 14.8 & 4.7 & 7.3 & 16.7 & 22.4 & 13.2 & 3.7 & 2.0 & 16.8 & 16.2 \\
\hline & Min & & 0.8 & 0.5 & 1.6 & 11.0 & 14.4 & 5.7 & 0.0 & 0.2 & 7.2 & 7.0 \\
\hline & Max & & 24.9 & 22.4 & 16.5 & 26.4 & 35.0 & 30.5 & 8.7 & 3.9 & 28.4 & 27.2 \\
\hline & A & & 24.1 & 22.0 & 14.9 & 15.4 & 20.5 & 24.8 & 8.7 & 3.7 & 21.1 & 20.3 \\
\hline & $S$ & & 7.4 & 6.9 & 5.5 & 5.0 & 6.9 & 8.1 & 3.1 & 1.2 & 8.0 & 7.1 \\
\hline & CV \% & & 49.8 & 145.7 & 75.0 & 29.9 & 30.7 & 61.3 & 83.2 & 59.8 & 47.6 & 44.1 \\
\hline
\end{tabular}

The highest values of force are highlighted in the region of the medial heel (Z9), lateral heel (Z10), toe I (Z1), followed by the metatarsal II, III and IV (Z4, Z5, Z6). The lowest values of the force are registered for the region of toes II-V (Z2), metatarsal V (Z7) and midfoot (Z8) of the plantar surface of the foot (Figure 3). The same trend could be seen in the case of pressure (Figure 4). Regarding the mean values for the contact time (Figure 5), higher values are recorded at the toe I, metatarsal II, III and IV, while in the heel area, these values decrease significantly. This distribution is specific to all three groups of analysed subjects. The highest contact area mean values (Figure 6) are recorded in the case of the midfoot, followed by the inner region of the heel for both left and right foot. The lowest values for contact area are noted in the region of metatarsal III and IV (Z5 and Z6).

The analysis of the chromatic maps generated by Footscan software and the evaluation of diagrams demonstrate that the most loaded, in terms of force and pressure, are toe I, metatarsal II-IV, lateral and medial heel, being in the same time the regions with the minimum contact areas. This conclusion is supported by previous studies, which confirm that the maximum loading and plantar pressure are transferred from heel to rearfoot. Thus, in the barefoot gait, the heel takes a load of about $57 \%$ and metatarsals $43 \%$ of the body weight, while the stresses in midfoot and toe II-V regions are not significant $[3,34]$. Some studies have reported that the highest pressure has been identified in the area of the toe I [35]; others highlighted the metatarsal II and III regions [32]. These differences in pressure distributions could be caused by the rules used to divide the plantar surface into regions, the software used for the analysis, the subjects involved in the study, the protocols, the experimental conditions, the characteristics of the sensor and the measurement technologies.

The mean values for the contact time are higher in the rear-foot regions and decrease on the heel area. A similar distribution is identified in the literature [36, 
37]. The values obtained justify that the heel strike phase is shorter than the support and propulsion phase and confirm that the contact time between the heel region and the support increases pressure [34].

The contact area is an important variable which in alliance with the pressure, provides valuable information regarding the loading model of the foot. As can also be identified in other studies [32, 36], this parameter has higher values in the heel and midfoot regions, which have the function of force absorption and pressure redistribution. In contrast, the metatarsal region has a significantly smaller contact area and higher pressures.



Figure 3. Mean force corresponding to each anatomical region of the plantar footprint for normal gait



Figure 4. Mean pressure corresponding to each anatomical region of the plantar footprint for normal gait 


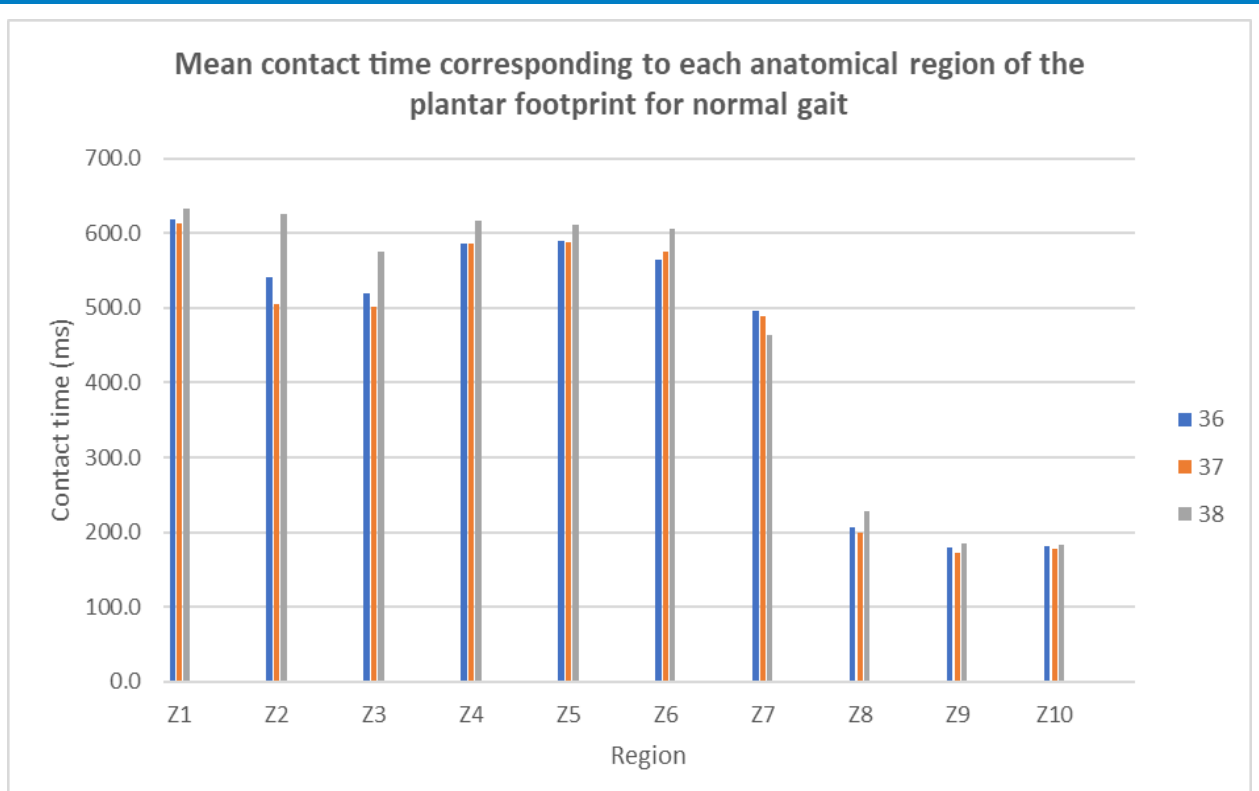

Figure 5. Mean contact time corresponding to each anatomical region of the plantar footprint for normal gait

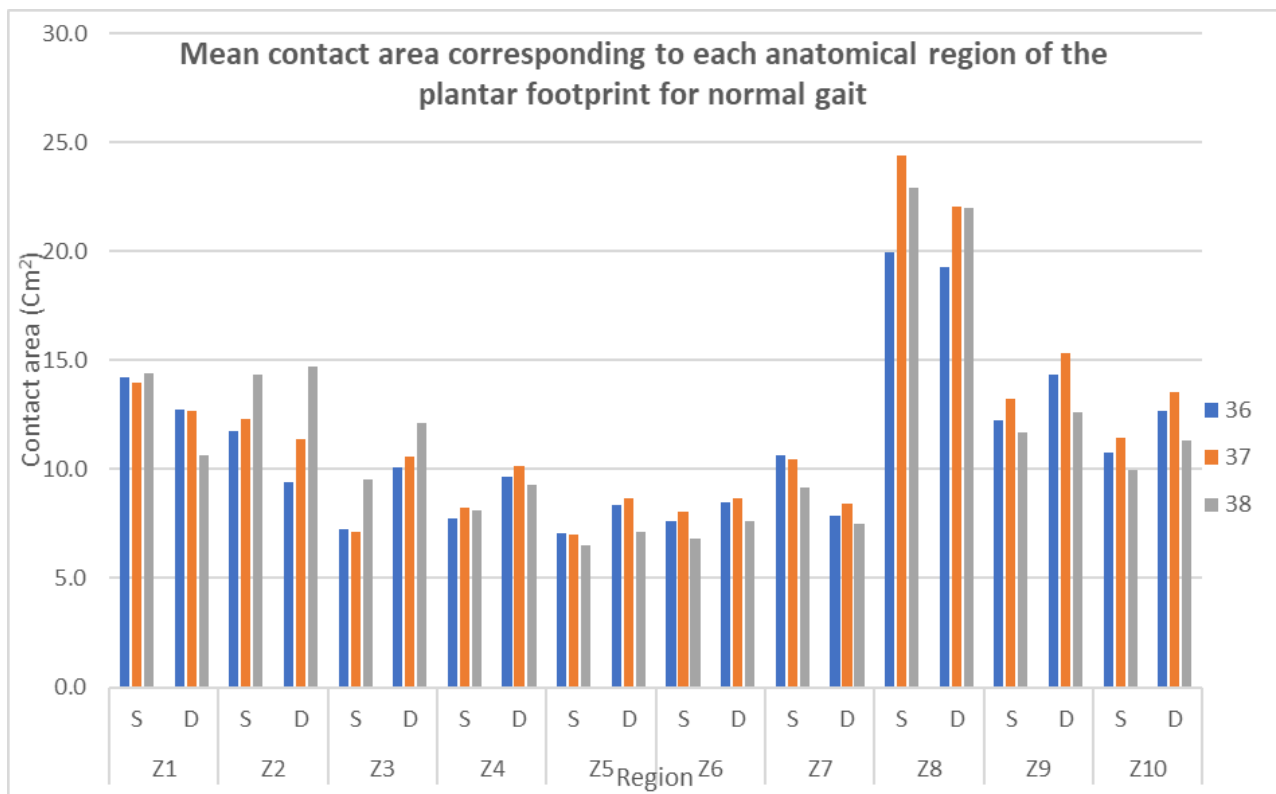

Figure 6. Mean contact area corresponding to each anatomical region of the plantar footprint for normal gait

Figures 7-10 represent the coefficients of variation of the studied biomechanical parameters graphically.

In the case of the group of subjects with size 36 , the highest values of the coefficient of variation for force and pressure parameters are on Z2 (toe II-V) - 83\%, Z7 (metatarsal V) $74.8 \%$ and $Z 8$ (midfoot) - 60.9\%, while the lowest values are for the contact time parameter on the Z1 (toe I) $-8.6 \%$ and Z4 (metatarsal II) - 9.5\% regions.
The coefficient of variation with maximum value for the group of subjects with size 37 has the parameter force and pressure on the Z7 (metatarsal V) - 107.5\%, Z3 (metatarsal I) - 89.9\% and Z2 (toe II-V) - 75.3\% regions, while the minimum values are observed for the contact time on Z1 (toe I) $6.2 \%$, Z4 (metatarsal II) $-6.9 \%$ and Z5 (metatarsal III) - 7.2\%.

The highest values of the coefficient of variation for the group of subjects with size 38 in case of force and pressure are on Z2 (toe II- 
V) - 113.2\%, Z7 (metatarsal V) - 96.3\% and Z8 (midfoot) $-82.3 \%$, while the lowest values are for the contact time parameter on $\mathrm{Z1}$ (toe I) $12.5 \%, \mathrm{Z2}$ (toe II-V) $-10.5 \%$ and $\mathrm{Z5}$ (metatarsal III) $-8.4 \%$.

Regarding the contact surface, higher values of the coefficient of variation are detected in the case of subjects with size 38 on Z3 (metatarsal I) - 74.8\%, Z2 (toe II-V), Z5 (metatarsal III) - 48.2\% and Z7 (metatarsal V) $48.8 \%$. For the group of sizes 37 and 36 , a minimum to medium dispersion over all 10 areas of the plantar footprint is highlighted.



Figure 7. Distribution of coefficient of variation for force (normal gait)



Figure 8. Distribution of coefficient of variation for pressure (normal gait) 




Figure 9. Distribution of coefficient of variation for contact time (normal gait)

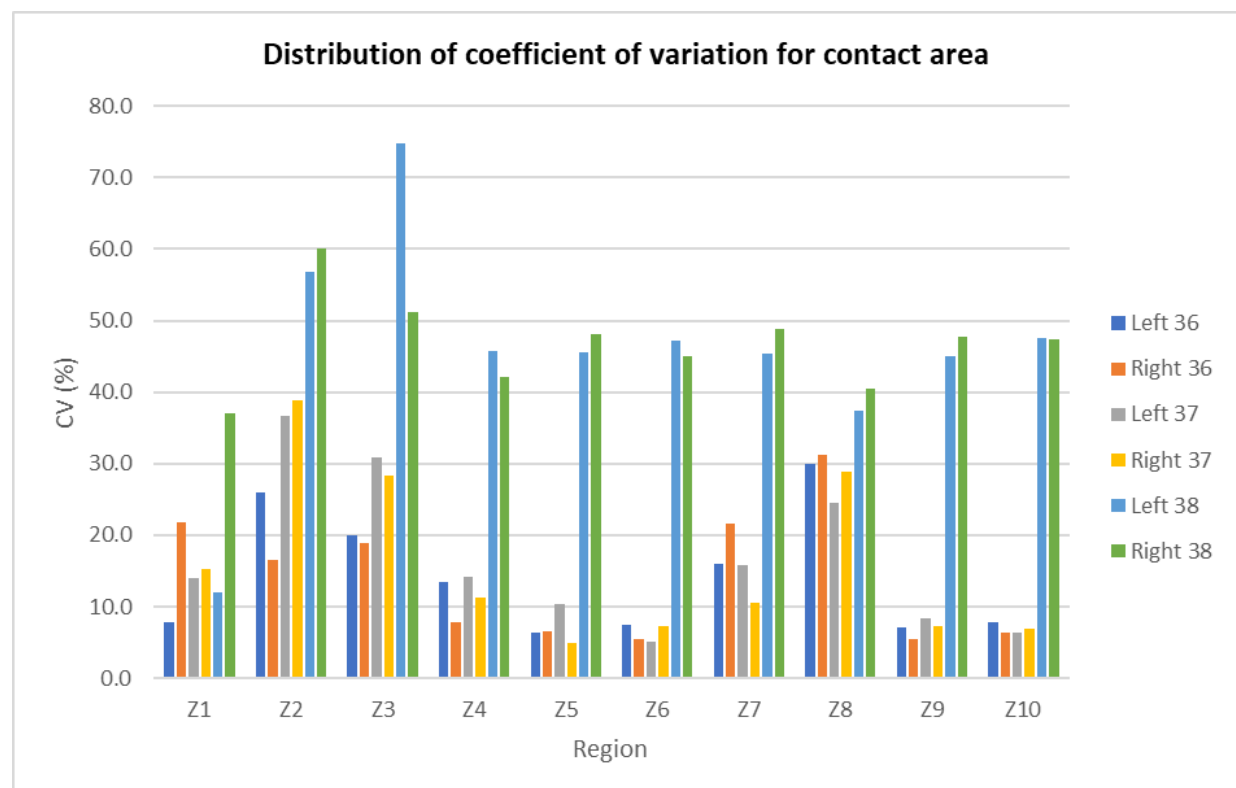

Figure 10. Distribution of coefficient of variation for contact area (normal gait)

\section{CONCLUSIONS}

The study evaluates the main variables in the biomechanical characterisation of gait force, pressure, time and contact area. The research was performed based on the data collected from 32 healthy females, aged between 18 and 30 years, divided into three size groups - 36 (10 subjects), 37 (13 subjects), 38 (9 subjects).

Due to the division of the plantar surface on 10 distinct regions, toe I (Z1), toe IIV (Z2), metatarsal I (Z3), metatarsal II (Z4), metatarsal III (Z5), metatarsal IV (Z6), metatarsal $\mathrm{V}$ (Z7), midfoot (Z8), medial heel
(Z9), lateral heel (Z10), the more and less loaded zones in terms of the forces acting during normal walking are identified. The obtained data were centralised and analysed from a statistical point of view.

The plantar pressures recorded in dynamics highlight the first toe, metatarsal IIIV, lateral and medial heel as the most loaded regions of the plantar surface. There are statistically significant differences between the left and right foot for the contact area parameter for all size groups in all plantar regions except midfoot. The analysis of statistical indicators for force variation highlights a medium and large dispersion, 
which describes the population as relatively homogeneous, and in some areas, even heterogeneous (CV is over 30\%). It confirms that the forces generated during the impact with the ground vary from one subject to another, being a parameter influenced by many external and internal factors [38]. Considering the coefficient of variation for force and pressure variables, smaller distributions on the toe II-V, metatarsal I, V and midfoot regions are confirmed. In contrast, the areas with higher values of forces and pressures - toe I, metatarsal II-IV, medial and lateral heel have smaller distribution, nearby $30 \%$ - which characterise a moderately homogeneous population. In terms of time and contact area, the coefficient of variation highlights a small and medium spread of values, and the population is considered homogeneous.

Based on this research, the average model of foot loading for an extended target group was created to be further used in simulations of footwear behaviour in various loading conditions.

\section{REFERENCES}

1. Dawe, E., Davis, J., Anatomy and

biomechanics of the foot and ankle, Orthop

Trauma, 2011, 25, 4, 279-286,

https://doi.org/10.1016/j.mporth.2011.02.004.

2. Malureanu, G., Mihai, A., Basics of footwear pattern making (in Romanian), Performantica lasi, 2003, 200-203.

3. Qian, Z., Ren, L., Ding, Y., Hutchinson, J.R., A Dynamic Finite Element Analysis of Human Foot Complex in the Sagittal Plane during Level Walking, PLoS One, 2013, 8, 11, 1-10, https://doi.org/10.1371/annotation/ce351 166-09b8-4a6b-bf8a-a0858670c034.

4. Filardi, V., Finite element analysis of the foot: Stress and displacement shielding, $J$ Orthop, 2018, 15, 4, 974-979, https://doi.org/10.1016/j.jor.2018.08.037.
5. Ferber, R., Osis, S.T., Hicks, J.L., Delp, S.L., Gait biomechanics in the era of data science, $J$ Biomech, 2016, 49, 16, 3759-3761, https://doi.org/10.1016/j.jbiomech.2016.1 0.033 .

6. Kaufman, K., An, K., Chapter 6 Biomechanics, Kelley and Firestein's Textbook of Rheumatology (Tenth Edition), eds.: G.S. Firestein, R.C. Budd, S.E. Gabriel, I.B. McInnes, and J.R. O'Dell, Elsevier, 2017, 78-89, ISBN 978-0-323-31696-5.

7. Fit2Com project, Basics of comfort for footwear, 2018, retrieved from https://www.fit2comfort.eu/

8. Bassile, C.C., Hayes, S.M., Chapter 9 - Gait Awareness, Stroke Rehabilitation (Fourth Edition), 2016, 194-223.

9. Esquenazi, A., Talaty, M., Assessment and Orthotic Management of Gait Dysfunction in Individuals with Traumatic Brain Injury, Atlas of Orthoses and Assistive Devices (Fifth Edition), eds.: J.B. Webster and D.P. Murphy, Philadelphia, 2019, 296-301, https://doi.org/10.1016/B978-0-32348323-0.00029-9.

10. Franklin, S., Grey, M.J., Heneghan, N., Bowen, L., Barefoot vs common footwear: A systematic review of the kinematic, kinetic and muscle activity differences during walking, Gait Posture, 2015, 42, 230-239,

https://doi.org/10.1016/j.gaitpost.2015.05.019

11.Sanchis, E., Sancho, J.L., Roda, A., Pascual, J., Kinematics and kinetics analysis of midfoot joints of 30 normal subjects during walking, Revista Española de Podología,

2016, 27, 2, 6-12, https://doi.org/10.1016/j.repod.2016.10.005. 
12.Carlson, J.M., CPO Functional Limitations from Pain Caused by Repetitive Loading on the Skin: A Review and Discussion for Practitioners, With New Data for Limiting Friction Loads, JPO Journal of Prosthetics and Orthotics, 2006, 18, 4, 93-103.

13. Nabiyouni, M., Saktheeswaran, A., Bowman, D.A., Karanth, A., Comparing the performance of natural, semi-natural, and non-natural locomotion techniques in virtual reality, 2015 IEEE Symposium on 3D User Interfaces (3DUI), 2015, 3-10, https://doi.org/10.1109/3DUI.2015.7131717.

14.Perttunen, J., Foot loading in normal and pathological walking, Studies in sport, physical education and health, 2002.

15.Jacob, H.A., Forces acting in the forefoot during normal gait-an estimate, Clin Biomech, 2001, 16, 9, 783-92, https://doi.org/10.1016/s02680033(01)00070-5, PMID: 11714556.

16. Wiedemeijer, M.M., Otten, E., Effects of high heeled shoes on gait, Gait Posture, 2017, 61, 423-430, https://doi.org/10.1016/j.gaitpost.2018.01.03.

17.Stefanyshyn, D.J., Nigg, B.M., Fisher, V., Flynn, B.O., Liu, W., The Influence of High Heeled Shoes on Kinematics, Kinetics, and Muscle EMG of Normal Female Gait, J Appl Biomech, 2000, 309-319.

18. Bergstra, S.A., Kluitenberg, B., Dekker, R., Bredeweg, S.W., Postema, K., Running with a minimalist shoe increases plantar pressure in the forefoot region of healthy female runners, J Sci Med Sport, 2015, 18, 4, 463-468, https://doi.org/10.1016/j.jsams.2014.06.007.
19.Altayyar, S.S., The Importance of Plantar Pressure Measurements and Appropriate Footwear for Diabetic Patients, J Anal

Pharm Res, 2016, 3, 3, https://doi.org/10.15406/japlr.2016.03.00 057.

20.Teymouri, M., Halabchi, F., Mirshahi, M., Mansournia, A., Ahranjani, A.M., Sadeghi, A., Comparison of plantar pressure distribution between three different shoes and three common movements in futsal, PLoS One, 2017, 1-10, https://doi.org/10.1371/journal.pone.0187 359.

21.Adamczyk, P.G., Kuo, A.D., Mechanical and energetic consequences of rolling foot shape in human walking, J Exp Biol, 2013, 216, 2722-2731, https://doi.org/10.1242/jeb.082347.

22. Luximon, Y., Luximon, A., Yu, J., Biomechanical evaluation of heel elevation on load transfer - experimental measurement and finite element analysis, Acta Mech Sin, 2012, 28, 232-240, https://doi.org/10.1007/s10409-012-0015-9. 23.Yu, J., Cheung, J.T., Wong, D.W., Cong, Y., Zhang, M., Biomechanical simulation of high-heeled shoe donning and walking, $J$ Biomech, 2013, 46, 12, 2067-2074, https://doi.org/10.1016/j.jbiomech.2013.0 5.009 .

24.Speksnijder, C.M., vd Munckhof, R.J., Moonen, S.A.F.C.M., Walenkamp, G.H.I.M., The higher the heel the higher the forefoot-pressure in ten healthy women, Foot, 2005, 15, 17-21, https://doi.org/10.1016/j.foot.2004.10.00. 
25.Franciosa, P., Gerbino, S., Lanzotti, A., Silvestri, L., Improving comfort of shoe sole through experiments based on CAD-FEM modeling, Med Eng Phys, 2013, 35, 1, 36-46, https://doi.org/10.1016/j.medengphy.201 2.03.007.

26.Yu, J., Wong, D.W., Zhang, H., Luo, Z., Zhang, M., The influence of high-heeled shoes on strain and tension force of the anterior talofibular ligament and plantar fascia during balanced standing and walking, Med Eng Phys, 2016, 38, 10, 1152-1156, https://doi.org/10.1016/j.medengphy.201 6.07.009.

27.Wang, Y., Li, Z., Wong, D.W., Finite element analysis of biomechanical effects of total ankle arthroplasty on the foot, J Orthop Transl, 2018, 12, 55-65, https://doi.org/10.1016/j.jot.2017.12.003.

28.Drougkas, D., Gait-Specific Optimization of Composite Footwear Midsole Systems, Facilitated through Dynamic Finite Element Modelling, Appl Bionics Biomech, 2018, https://doi.org/10.1155/2018/6520314.

29.Chen, T.L., Wong, D.W., Wang, Y., Lin, J., Zhang, M., Foot arch deformation and plantar fascia loading during running with rearfoot strike and forefoot strike: $A$ dynamic finite element analysis, J Biomech, 2019, 83, 260-272, https://doi.org/10.1016/j.jbiomech.2018.1 2.007 .

30. Sârghie, B., Contributions to the modelling and simulation of the behavior of military footwear during use (in Romanian), PhD Thesis, 2013, https://doi.org/10.13140/RG.2.2.11426.63689.
31.Xu, C., Wen, X., Huang, L., Shang, L., Cheng, X., Yan, Y., Lei, W., Normal foot loading parameters and repeatability of the Footscan ${ }^{\circledR}$ platform system, Foot Ankle Res, 2017, https://doi.org/10.1186/s13047-017-0209-2.

32.Van der Leeden, M., Dekker, J.H., Siemonsma, P.C., Lek-Westerhof, S.S., Steultjens, M.P., Reproducibility of plantar pressure measurements in patients with chronic arthritis: a comparison of one-step, two-step, and three-step protocols and an estimate of the number of measurements required, Foot Ankle Int, 2004, https://doi.org/10.1177/10711007040250 1008. PMID: 15566706.

33.Voineagu, V., Tiţan, E., Ghiţă, S., Boboc, C., Todose, D., Statistics. Theoretical bases and applications (in Romanian), Editura Economică, Bucharest, 2007.

34. Petrović, S., Devedžić, G., Ristić, B., Matić, A., Stojanović, R., Foot pressure distribution and contact duration pattern during walking at self-selected speed in young adults, 2nd Mediterranean Conference on Embedded Computing (MECO), 2013, 172-175, https://doi.org/10.1109/MECO.2013.660134. 35.Maetzler, M., Bochdansky, T., Abboud, R.J., Normal pressure values and repeatability of the Emed 1 ST2 system, Gait Posture, 2013, 32, 3, 391-394, https://doi.org/10.1016/j.gaitpost.2010.06.02.

36. Putti, A.B., Arnold, G.P., Cochrane, L.A., Abboud, R.J., Normal pressure values and repeatability of the Emed 1 ST4 system, Gait Posture, 2008, 27501-505, https://doi.org/10.1016/j.gaitpost.2007.06.00. 
37. Putti, A.B., Arnold, G.P., Cochrane, L.A., Abboud, R.J., The Pedar 1 in-shoe system: Repeatability and normal pressure values, Gait Posture, 2007, 25, 401-405, https://doi.org/10.1016/j.gaitpost.2006.05.01.
38.Mei, Z., Zhao, G., Ivanov, K., Guo, Y., Zhu, Q., Zhou, Y., Wang, L., Sample entropy characteristics of movement for four foot types based on plantar centre of pressure during stance phase, Biomed Eng, 2013, https://doi.org/10.1186/1475-925X-12-101.

(C) 2021 by the author(s). Published by INCDTPICPI, Bucharest, RO. This is an open access article distributed under the terms and conditions of the Creative Commons Attribution license (http://creativecommons.org/licenses/by/4.0/). 